\title{
Enfermagem: a credibilidade do cuidado
}

$\mathrm{N}$

o processo de construção do conhecimento e ocupação do mercado de trabalho, diversas profissões buscaram estabelecer o seu referencial teórico para que não houvesse dúvidas quanto à base científica que sustentam o seu saber. Na enfermagem, seja enquanto profissão ou enquanto área do conhecimento, também se tem buscado a formação cada vez mais sólida das bases que nos diferenciam das outras profissões do setor da saúde.

A Revista Enfermagem em Foco, desenvolvida pelo Conselho Federal de Enfermagem, é uma das grandes ferramentas criadas para difundir o conhecimento científico produzido pelos pesquisadores e para apresentar à comunidade o saber próprio da Enfermagem.

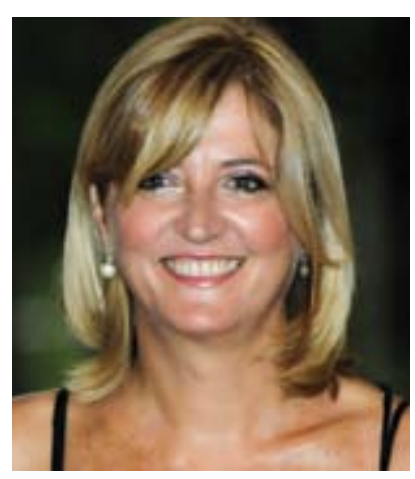
Essa ação busca não apenas uma valorização no âmbito acadêmico, mas trazer a praxis ao nosso cotidiano. Assim construímos uma "credibilidade empírica".

A importância deste periódico é incalculável e a sua leitura deve ser incentivada pelas faculdades, universidades e também pelos profissionais que atuam na prática, uma vez que aquilo que construímos enquanto ciência é o que viabiliza a formação de uma técnica eficiente e que faz a diferença para o cuidado ao outro - essência da nossa profissão.

Os artigos que você lerá ao longo desta revista possuem a finalidade de apresentar algo além do senso comum. E isso auxilia o fortalecimento da nossa credibilidade - conquistada a "duras penas" diariamente. Por isso a revista tende a crescer e a leitura de sua versão digital deve ser estimulada, tornando-a acessível a todos aqueles que se interessam pelo saber próprio da Enfermagem.

Sei que nossa profissão luta por uma valorização em quesitos salariais e sindicais. Mas é tornando a enfermagem cada vez mais única, com seu saber cada vez mais aprofundado, e com uma técnica cada vez mais excelente, que conquistaremos aquilo que quisermos, ou melhor, merecemos!

Essa é uma das diversas propostas da nova gestão do Cofen, que carrega o lema "Consolidar as Conquistas e Avançar". Todas as ações desenvolvidas pelo nosso Conselho nos últimos anos foram grandes passos rumo a um retorno da credibilidade do nosso sistema e, baseado nesses avanços, poderemos chegar mais longe e garantir aos nossos profissionais o devido reconhecimento. Para isso, esta revista é fundamental. Necessitamos de produção científica que nos traga novos olhares, novas relações e novas tecnologias. Fortalecendo a nossa profissão, fortalecemos os nossos profissionais.

Tenha uma ótima leitura. 